\author{
NBER WORKING PAPER SERIES \\ ON \\ HISTORICAL FACTORS IN LONG RUN GROWTH
}

\author{
WHAT DETERMINES THE ALLOCATION \\ OF NATIONAL GOVERNMENT GRANTS \\ TO THE STATES?
}

John Joseph Wallis

Historical Paper 90
NATIONAL BUREAU OF ECONOMIC RESEARCH
1050 Massachusetts Avenue
Cambridge, MA 02138
July 1996

Some of the data in this paper are the result of the generosity of Gavin Wright, and the support of George Stigler when I was a fellow at the Center for the Study of the Economy and the State long ago. Farley Grubb was my research assistant then, and I have more recently been helped by Robert Satterfield and Brad Lewis. Wally Oates, Shawn Kantor, Price Fishback, and the Development of the American Economy program meeting participants provided helpful comments. This paper is part of NBER's research programs in the Development of the American Economy, and Public Economics. Any opinions expressed are those of the author and not those of the National Bureau of Economic Research.

(C) 1996 by John Joseph Wallis. All rights reserved. Short sections of text, not to exceed two paragraphs, may be quoted without explicit permission provided that full credit, including $(\odot$ notice, is given to the source. 
NBER Historical Paper 90

July 1996

\title{
WHAT DETERMINES THE ALLOCATION OF NATIONAL GOVERNMENT GRANTS TO THE STATES?
}

\begin{abstract}
During the New Deal the federal government initiated a policy of massive grants to states for support of social welfare and other programs. Since that time grants have come to be an integral part of the American fiscal system, and scholars have continued to debate whether the allocation of federal grants between the states is motivated primarily by political or social and economic objectives. This paper shows that, during the 1930s, both political and economic effects were important determinants of grant allocation, but that the Congressional factors considered by Anderson and Tollison are not important while the Presidential factors considered by Wright are. When the analysis is extended to the years 1932 to 1982, however, Congressional influences do seem important. On the other hand, the dominant influence on federal grant policy over the larger sample appears to be state government expenditures, while both political and economic influences play a smaller role.
\end{abstract}

John Joseph Wallis Department of Economics University of Maryland College Park, MD 20742 and NBER 


\section{INTRODUCTION}

One of the most prominent changes in the structure of the American fiscal system in the twentieth century is the growing importance of federal government grants-in-aid to state and local governments. At the turn of the century federal grants to state and local governments were $\$ 7$ million, too small to warrant separate treatment in the Annual Report of the Secretary of the Treasury. In 1992 , federal grants totaled $\$ 171,400$ million. They account for $11.1 \%$ of total federal government expenditures (17.5\% of non-military expenditures) and 20 percent of state and local revenues. ${ }^{1}$ As important as their fiscal magnitude, intergovernmental grants have become an integral part of financing expenditures for education, welfare, and transportation infrastructure. The current debate over the size and role of the federal government necessarily involves rethinking the fiscal structure of all three levels of government, since major changes in federal government expenditures are only possible through major changes in grant policy. Welfare

reform, for example, is as much about which level of government will tax and spend as it is about how much will be spent.

While the economic theory of intergovernmental grants is well developed, the empirical study of the determinants of grants has focused as much on politics as on economics. ${ }^{2}$ Political factors are almost always important determinants of the allocation of federal grants between states, and often are quantitatively more important determinants of grant policy than economic variables like income or urbanization. Whether a state is critical to a President's re-election or is represented by a powerful Congressman appears to affect grants as much or more than whether a state has low income, and therefore should qualify for larger redistributive grants, or has a larger urban population, and therefore should qualify for larger urban targeted grants. In fact, states 
with higher incomes often appear to receive larger grants. These conclusions suggest that the enormous growth in federal government grants may not be the result of attempts at fiscal rationality, but may instead be an enormous pork-barrel boondoggle imposed on the American taxpaying public for the political benefit of incumbent Presidents and Congressmen.

The results have a direct impact on historical and current debates. The allocation of federal government grants during the New Deal administration of Franklin Roosevelt has received a great deal of attention. ${ }^{3}$ The focus on the New Deal is understandable, since expansion of federal grants were central to New Deal programs in agriculture, social welfare, and infrastructure investment. Federal expenditures grew from $\$ 4.3$ billion in 1932 to $\$ 10.1$ billion in 1940 , while expenditures in "cooperatively administered programs" rose from $\$ .2$ billion to $\$ 3.9$ billion, two thirds of the increase. ${ }^{4}$ Our view of the New Deal is much different if these grant programs, which represent the cutting edge of liberal social reform in American history, were driven primarily by partisan political concerns. ${ }^{5}$

The current debate over the size and structure of the federal government is intimately tied up with the nature and operation of grants. Federal expenditures for welfare, education, and transportation are made primarily through intergovernmental grants. Since the Reagan administration there has been an ongoing debate about whether these functions should be returned to the states. Arguments for keeping some measure of administrative control and financial discretion at the national level are considerably weaker if it appears that national control serves ends that are primarily political. This is even more true if grants that are, in a general way, designed to redistribute income and help urban areas, are less likely to go to states with low incomes and large urban populations. 
Recent advances in the study of grant allocation have focused on the political side. Anderson and Tollison explored the use of a new set of variables that represent Congressional politics during the New Deal. This paper also expands the set of political variables that affect grants. The existing set of political variables are designed to pick up "swing" states. One might expect that Democratic President would direct larger amounts of funds to states that traditionally vote Democratic. But shifting the vote 1 percent toward the Democrats in a state where Democrats traditionally receive 70 percent of the vote is much less productive than an equivalent grant and 1 percent vote shift would be in a state where Democrats traditionally receive 49 percent of the vote. While the logic is sound, over the long term it implies that the Democrats (or Republicans) systematically ignore their strongest supporters in favor of states that more often support their opponents. This logic underlies the construction of Wright's "political productivity" variables as well as Anderson and Tollison's focus on key Congressional leaders who can swing the legislative process. Using data covering years from 1932 to 1982 , it is possible to distinguish between the response of grant allocation to the level of political support in a state as well as the importance that each state possesses as a potential swing state.

The major emphasis of the paper, however, is not on improving the set of useful political variables. The econometric specifications used in most studies look at simple cross sections of states and focus solely on the behavior of the federal government. Many grant programs, however, contain explicit or implicit matching provisions to provide state governments with an incentive to supplement grant moneys with their own tax dollars. Consideration of the simultaneity of state spending decisions and federal grant allocations is very important. Federal grant allocations also have a significant idiosyncratic state specific component. When state fixed 
effects are controlled for, the empirical results change dramatically. This paper uses a more appropriate econometric specification to ascertain what determines the allocation of federal grants. I find that both political and economic factors matter statistically; that the economic factors exert the right kind of influence on grants; and that quantitatively the effects of both political and economic factors are rather small. By contrast, the effect of state expenditures on federal grants is statistically significant and quantitatively large. Variations in state expenditures explain a large part of the variance in federal grants over time and across states.

After considering a few methodological issues, I briefly re-examine the conclusions of the New Deal literature using a comparable data set to re-estimate Wright, Anderson and Tollison, and my earlier work. A full investigation is then done on a long panel data set, including information from the 1932,1942, 1962, 1972, and 1982 Censuses of Governments. Unlike the 1930s data, all of the economic and political variables in the large data set vary over states and time, and complete state and local fiscal information is available for each year. With the 20th century data set we can draw firm conclusions about the relative effect of economic, political, and state fiscal variables on the allocation of national grants between the states.

\section{Some Methodological Considerations}

One model of the grant process pictures federal government officials structuring grant allocations to maximize the value of those grants to themselves and/or their constituents. Congress decides the formulas under which some grants will be allocated and the executive branch has discretionary control in the awarding of other grants. This translates into an estimating equation of the form: 
(1) $\mathrm{FG}_{\mathrm{i}}=\alpha+\beta \mathrm{E}_{\mathrm{i}}+\gamma \mathrm{P}_{\mathrm{i}}+\epsilon$

where $\mathrm{FG}_{\mathrm{i}}$ is per capita federal grants to state $I ; \mathrm{E}$ and $\mathrm{P}$ are vectors of economic and political variables; and the error term, $\epsilon$, is a normal white noise error.

Equation (1) is not, however, an accurate representation of how the grant allocation process actually works. Grants are typically allocated through a series of formulas that include factors like population, income, or highway mileage, as well as measures of state (or local) financial participation. ${ }^{6}$ Congress may have in mind an allocation of grants that reflect economic and political factors, but state and local governments have independent input into the allocation process. At one extreme, with strict matching, federal grants are simply a linear function of state expenditures. This was true for all of the categorical assistance programs put in place in the Social Security Act of 1935, and is still true today. Many grants fall short of strict, open ended matching formulas, but many involve some attempt to reward states that make a larger effort to cooperate with the federal goals by rewarding those states with larger grants. ${ }^{7}$

States also differ in ways not captured by economic or political variables, or captured only imperfectly. These persistent differences between states produce significant differences in state fiscal activity, as well as persistent differences in grants. These "fixed effects" can be controlled for if we have a panel data set that varies over time.

A more appropriate set of estimating equations are:

(2) $\mathrm{FG}_{\mathrm{it}}=\alpha_{\mathrm{g}}+\beta \mathrm{E}_{\mathrm{it}}+\gamma \mathrm{P}_{\mathrm{it}}+\mathrm{SX} \mathrm{Xit}_{\mathrm{it}}+\epsilon_{\mathrm{i}}+\epsilon_{\mathrm{i}}+\epsilon$

(3) $\mathrm{SX}_{\mathrm{it}}=\alpha_{\mathrm{x}}+\lambda Z_{\mathrm{jt}}+\xi \mathrm{NG}_{\mathrm{it}}+\epsilon_{\mathrm{si}}+\epsilon_{\mathrm{st}}+\epsilon_{\mathrm{s}}$ where subscripts $I$ refers to states and $t$ refers to time, SX is state expenditures, $Z$ is a vector of variables explaining state expenditures, and $\epsilon_{\mathrm{s}}$ 's are the errors for the state expenditure equation. ${ }^{8}$ 
If equation (1) is estimated when equations (2) and (3) are true then the equation (1) estimates will suffer from several defects. One will be omitted variable bias. This may be a problem for all variables, but it turns out to be particularly important for some of the political variables. The political variables tend to be stable over significant period of time and are correlated with $\epsilon_{\mathrm{i}}$ and $\epsilon_{\mathrm{i}}$. The coefficients on the political variables, therefore, are sensitive to the specification of the error term.

Second, even if state and local expenditures are included as economic variables in equation (1), the estimates will suffer from simultaneity bias. This turns out to be important for a number of coefficients, the most important being per capita income. The professed goal of many federal grant programs is to redistribute income. But in the United States, the bulk of social welfare spending is under the direct control of the states, financed by matching grants from the federal government. If states with higher incomes tend to spend more on social welfare, then estimates of equation (1) will tend to show that states with higher incomes receive larger grants, in direct contradiction to the stated goals. One of the more persuasive pieces of evidence supporting the case that political factors are more important than economic factors is that some economic variables, like income, appear to have a perverse effect on grants. If this result is, however, an artifact of the estimation technique, then support for the political factors argument is considerably reduced.

\author{
III. The New Deal
}

Leonard Arrington was the first to notice a peculiarity in the allocation of New Deal expenditures across states. ${ }^{9}$ They tended to be highest in states with relatively high incomes in the 
West, and lowest in states with relatively low incomes in the South, despite the fact that the South was solidly Democratic. If Roosevelt were rewarding his supporters the Southerners should have receive the largest grants per capita, not the smallest grants. ${ }^{10}$ Reading implemented an econometric analysis of New Deal grants using report published by the Office of Government Reports, Statistical Section in $1940 .{ }^{11}$ He found support for the idea that New Deal expenditures were intended to promote the natural resources of the country (as measured by the percentage of land in a state owned by the federal government) and to compensate for the effects of the Depression, but found no support for the idea that New Deal programs promoted reform. Wright, using Reading's data, tested the hypothesis that political considerations were an important part of the allocation process. ${ }^{12}$ Wright found that his political variables did a much better job of explaining the patterns of expenditures across states than did the economic variables.

Because of data limitations, both Reading and Wright focused on the federal government and limited themselves to one cross-section of 48 states, covering the entire period from 1933 to 1939. Most of the New Deal programs were intergovernmental, not national, and many involved explicit or implicit matching grants. Unfortunately, state and local government expenditures are not available over the years 1933 to 1936 . I showed that federal grant policy was responsive to state and local spending after $1936 .{ }^{13}$ In a second paper, I incorporated information on annual state level employment and annual per capita income to create a panel of seven years and forty eight states. ${ }^{14}$ Using the panel data set, it was apparent that both economic and political factors had an effect on New Deal policy. On balance it appeared that the economic effects may have been more important quantitatively than the political effects, but the total effect on grants was relatively small. Neither political or economic factors alone, as proxied by employment and 
Wright's political productivity measure, drove New Deal allocation policy.

Anderson and Tollison have suggested that Wright and I erred in our characterization of the political process. ${ }^{15}$ Wright's political measures are built around voting returns from presidential elections. Congress, however, exercises an important role in the allocation of federal grants and spending through the choice of allocation formulas and control over agency funding. They incorporated several variables that proxied for the political influence of Congressional members -- key leadership positions, tenure in office, and tenure on the appropriations committees -- and found that these Congressional political variables had an important effect on the allocation of New Deal expenditures.

All of these papers use Reading's data set, taken from the Office of Government Reports documents. But inconsistencies in how variables are measured or calculated make direct comparison of their results difficult. The replicated estimates that follow utilize a common data set, based on Reading's original data and the following variable definitions:

The economic variables include the proportion of the population living on farms; the change in per capita income, 1929 to 1933 (measured as a percentage of 1929 income); the percentage of land owned by the federal government in each state; unemployment rates in 1937; and total farm value per capita in 1929 including land, buildings, implements and machinery, and livestock.

The political variables are broken into two groups, the presidential variables and the congressional variables.

The presidential variables were constructed by Wright. He collected information on the Democratic share of the presidential vote from 1896 to 1932, and fitted a linear trend to the data 
to "predict" the vote in 1936. Then using information on the standard deviation around the trend, he constructed a voting distribution for each state, with the predicted mean and the observed standard deviation. He then evaluated the probability that the democratic vote would be 50 percent or greater, $\operatorname{Pr}_{0}$, and compared that to the probability that the vote would be 50 percent or greater if the whole distribution was shifted 1 percent towards the Democrats, $\operatorname{Pr}_{1}$. The change in the probability of a democratic victory was then multiplied by the number of electoral votes a state controlled, and divided by one percent of the voting population. ${ }^{16}$ Wright also included the standard deviation of the Democratic share of the presidential vote over the preceding ten elections as a measure of how easy it might be to influence voters in a state, arguing that voters in states with high standard deviations might be easier to influence through grants.

I constructed an alternative version of Wright's political productivity index for each state in $1932,1942,1962,1972$ and 1982. I took the democratic share of the vote in the ten preceding presidential elections, and calculated the mean and standard deviation of that sample. Assuming a normal distribution, I then calculated the difference in the probability of receiving 49 and 50 percent of the vote, $\operatorname{Pr}_{.01}=\operatorname{Pr}_{._{49}}-\operatorname{Pr}_{.50}$. Then I multiplied by the number of electoral votes and divided by population to get the political productivity measure.

Anderson and Tollison do not use Wright's measures. The heart of Anderson and Tollison's argument is that key Congressional leaders should have been able to obtain larger grants for their constituents. They used six measures, three each for the Senate and the House. In the Senate these are: a dummy variable if a state's Senator was President Pro Tem or Senate Majority Leader during the period from 1933 to 1939, the length of consecutive tenure in months of the state's Senate delegation in December 1937, and the length of consecutive tenure in 
months of Senators serving on the Senate Appropriations Committee in December 1937. The House variables are the same, with the exception that the House leadership positions are Speaker of the House and Majority Leader. They also include electoral votes per capita, the state's rank in electoral votes per capita, and Roosevelt's share of the total.vote in the 1932 election. I have made some changes to their data to fix some apparent errors and to facilitate comparison with the rest of the century. ${ }^{17}$

There is, however, a serious problem with Nevada. The Senate leadership variable is based on whether a state's Senator was the majority leader or President Pro Tem. Since Key Pittman of Nevada was President Pro Tem for the entire period, Nevada gets a 1 in the dummy variable for Senate leadership. Unfortunately, Nevada also receives far and away the largest per capita grants. In Reading's total allocations Nevada receives $\$ 1,499.39$, fully one half again as much as the next state, Montana with $\$ 986.30$, and more than triple the national average. Not surprisingly, Senate leadership is consistently positive, both in Anderson and Tollison's results and in the panel results for the 1930s. Anything that proxies for Nevada will be positive. Anderson and Tollison also estimate several specifications including electoral votes per capita, which also picks up the Nevada effect. Electoral votes per 1,000 population in Nevada is .039 . The state with the next highest value is Delaware with .012 . The state with the lowest value is New York with .0037 . The national average is .006 , with a standard deviation of .0044 . Nevada is seven standard deviations from the mean, with three times the value of the next state, and five times the mean value. ${ }^{18}$

Table 1 reports variable means and standard deviations for the simple cross section of 48 states used by Wright and by Anderson and Tollison, and the panel data set with six years of data 
used by Wallis. The dependent variable in the regressions that follow is per capita expenditures as reported by Reading, measured in 1935 dollars. Table 2 replicates the original specifications of Anderson and Tollison, Wright, and Wallis specification: in columns (1), (2), and (3). In order to facilitate comparisons, all replications use the same dat: !efinitions. The original estimates can be found in Appendix table 2A. Differences between the os inal and replicated results are due to different scales for some variables, different measures of income decline between 1929 and 1933, and minor improvements made to the employment index and to the spending variables since the original studies were published. Columns (4) and (5) of the table present a full panel specification. Grants and the employment index are treated as endogenous variables to account for the possibility that more relief funds, and therefore more grants, would go to areas where employment was lower. ${ }^{19}$ These regressions include an annual state level employment index, annual real per capita income, lagged real per capita spending, and drop the unemployment variable. To account for the Nevada effect, column (5) of the table excludes Nevada.

A direct test of Anderson and Tollison's hypothesis that congressional political factors influence grants against Wright's hypothesis that presidential political factors influence grants is reported in columns (4) and (5). Nevada is critical. Excluding Nevada from the data set eliminates the coefficient and significance of Senate leadership, the only Congressional political variable with any statistical power. Excluding Nevada also weakens the effect of Wright's political productivity variable, but the standard deviation in Presidential voting still remains positive and significant. It is difficult to find strong support for the Anderson and Tollison hypothesis in these results.

The regressions enable a direct test of the New Dealer's claim that funds were went to 
states with lower employment (higher unemployment). Neither Wright nor Anderson and Tollison found that higher unemployment led to larger grants (columns (1) and (2)). But as I found earlier, when a panel data set is used, higher employment does lead to significantly smaller grants. States with higher incomes still receive higher grants, contradicting any suggestion that the New Deal was giving more money to poorer states. But state expenditures rise when state incomes rise, and therefore matching grants also rise, and we are unable to control for that simultaneity in this data set.

In general, the regressions suggest that economic factors were more important determinants of grants than political factors. Grants rise significantly with farm population, farm value, and income, and fall significantly as employment rises. A one standard deviation improvement in employment would reduce grants by about 8.5 percent $(\$ 3.74$ per capita per year), while a one standard deviation increase in the political productivity index would raise grants by about 3 percent ( $\$ 1.22$ ) and a one standard deviation increase in the variability of voting would raise grants by about 5 percent $(\$ 2.23)$. When a state's Senator obtains a leadership post grants increase by 21 percent ( $\$ 9.25$ per year per capita), but only if you happen to live in Nevada. None of the other Congressional influence variables have much impact on spending, and the only statistically significant result is that states with longer tenured Senators receive slightly smaller grants.

In short, Anderson and Tollison's conclusion that congressional political interests were important rests firmly on Key Pittman and the anomalous experience of Nevada. Wright's conclusions that political factors were more important determinants of grants than economic factors is unwarranted, although the presidential political factors he identified still have 
explanatory power. If we want to disentangle these issues further we need better data.

\section{Beyond The New Deal}

While the New Deal was a fundamental turning point in the history of intergovernmental grants, it may not the best time period to study the determinants of those grants. There are data limitations, particularly on state and local government finances. The period is short, so several key variables do not vary over the sample, such as Key Pittman's tenure as President Pro Tem of the Senate. Finally, the kind of Congressional forces that Anderson and Tollisson suggest should affect grants are more likely to do so over longer periods of time. Congress affects grant allocations through changes in the rules and formulas that are used to allocate grants, while the Executive branch is able to directly and immediately affect the allocation of grants through discretionary provisions in the grant legislation. By examining grant allocation over a longer period of time and using more detailed political control variables, both the congressional and presidential effects on grants become clearer. It is also possible to delineate the effects of state and local expenditures on federal grants.

A new data set was constructed around the information available on federal government grants to states measured in real dollars per capita, with 1967 as the base year. Data on state and local expenditures were taken from the Census of Governments in 1932, 1942, 1962, 1972, and 1982, the five years in the panel. Unfortunately, the Census was not conducted in 1952, and there are no comprehensive numbers on local government expenditures in that year. The political productivity measures were constructed for each year based on the preceding ten elections. The congressional variables were constructed in a similar manner, only tenure is counted in years 
rather than months, from the opening date of the relevant session of Congress. Farm value is measured as the real value, per farm, of land and buildings. Farm population was dropped in favor of the percentage of the population living in urban areas. The percentage of land in a state belonging to the federal government was dropped because it has very little variation over the century. The percentage of the population that is white was included from the Reading specification.

Anderson and Tollison noted the problems with collinearity between tenure of the House delegation and the tenure on the House Appropriations Committee. Since control of the House rested with the Democratic party in every year in the sample, I constructed an alternative measure of Appropriations Committee tenure which avoids the collinearity problem and produces some interesting results. I counted the tenure of the Democratic members separately from the Republican members, producing four appropriations committee tenure variables, one for the tenure of each party's delegations in the House and Senate committees. House and Senate leadership positions were also entered separately, so there are also four leadership variables.

Means and standard deviations for the variables are found in Table 3. Regression results are found in Table 4, where the dependent variable in every regression is real per capita federal grants. The first column of Table 4 begins with a simple pooled analysis. This regression is similar to the final specification from columns (4) and (5) of Table 2. The results, however, are substantially different. Presidential variables appear to have no statistical impact on grants. The overall tenure of a state's Senate delegation and the tenure of the state's Representatives on the House Appropriations committee is positive and significant. But the overall tenure of a state's House delegation exerts a negative impact on per capita grants. Further states with higher 
incomes receive significantly larger grants and more urban states receive significantly smaller grants.

As mentioned earlier, the political variables used so far are basically swing variables. They measure how close a state's vote is to 50 percent Democratic, how variable its voting pattern is, or whether a state's congressmen are in key decision making positions. But what about rewarding loyal voters? Column (2) of the table includes two political variables that measure voter support for the current President and the party of the current President. "Previous Winning Presidential Vote" is the share of the presidential vote that went to the winning candidate in the previous election. For example, in 1932 the variable measures Hoover's percentage of the popular vote in the 1928 election, while in 1942 the variable measures FDR's percentage of the popular vote in the 1940 election. The variable "Average Winning Presidential Vote" measures the average vote for the party of the current president in the previous ten elections. So the 1932 variable measures the average Republican share in the popular vote from 1892 to 1928 , while the 1942 variable measures the average Democratic share of the vote from 1904 to 1940. The sign on the previous Presidential vote is negative, indicating that President's do not reward their supporters, although this conclusion is sensitive to specification. Long term voting patterns appear to have little affect on grant allocation. ${ }^{20}$

Most of the results in column (2), however, are sensitive to changes in specification. The first change is adding state and local expenditures, treating each as an endogenous variable. A set of demographic and fiscal variables are used as instruments for state and local expenditures in the two stage estimates. ${ }^{21}$ The primary effect of including state and local expenditures is to alter the effect of income on grants. The coefficient on per capita income falls from .05 with a t-statistic of 
22 to .003 with a t-statistic of .8 . States with higher incomes spend more money and, as a result, receive higher grants. The perverse affect of income on grants appears to be due to this simultaneity, not to the fact that grants programs are designed to give more money to higher income states.

While including state and local expenditures has minor effects on other variables, the inclusion of fixed time and state effects dramatically changes the estimates. Time and state effects are included column (4). The coefficients on the time and state dummies are not included in the table. F-statistics on the test restricting the fixed effects at zero are presented in the last row of the table. The fixed effects are jointly significant at the 1 percent level.

Comparison of column (4) with column (3) of the table shows how important the fixed effects are. The Presidential political productivity coefficient doubles and becomes significant. The standard deviation of the democratic share of the vote becomes insignificant. The percentage of a state's population that is urban now exerts a positive and significant affect on grants instead of a negative effect, while income exerts a negative but not significant affect. State government expenditures remain an important positive determinant of grants, and local expenditures become statistically insignificant.

The results in Table 4 indicate the specification dangers inherent in these estimates. Major results are reversed when more appropriate specifications are adopted. Using the coefficient estimates in column (4) as a baseline, we can draw some conclusions regarding the relative importance of political, economic, and fiscal factors in the allocation of grants.

Wright's presidential political productivity index and Democratic tenure on the House Appropriations Committee are significant political variables, both statistically and quantitatively. 
A one standard deviation increase in the political productivity index produces a $\$ 3.66$ change in grants per capita per year, a 5 percent shift in the mean annual grant of $\$ 72$. Increasing a state's Democratic tenure on the Appropriations committee by a standard deviation of 10.22 years produces a $\$ 5$ increase in grants, a shift of 7 percent. Increasing the tenure of a state's Senate delegation always increases grants, though significance is specification sensitive, and an increase of eleven years produces an increase of $\$ 1.54$, a shift of only 2 percent. Republican tenure on the both Appropriations committees, however, is consistently negative and significant when fixed effects are controlled for. A one standard deviation increase in Republican committee tenure reduces grants by $\$ 3.37$ in the House and $\$ 2.64$ in the Senate.

The Senate Majority Leader seems to exert the most important affect on grant allocations. When a state's Senator becomes majority leader per capita grants rise by $\$ 17.68$, an increase of 25 percent over the mean annual grant. It is more difficult to evaluate the overall impact of this variable, since a one standard deviation increase in the Senate majority leader would produce an increase in grants of only $\$ 2.47$. It is, of course, impossible to have a .14 increase in the majority leader.

The quantitative impact of the key economic variables is larger than any of the political variables except for the Senate majority leader (although the income and local government coefficients are statistically insignificant). Increasing percent urban by a standard deviation raises grants by $\$ 8.27$ or 11 percent and increasing income by a standard deviation lowers grants by $\$ 7.99$ or 11 percent. The fiscal variables are quite important. Increasing local expenditures by a standard deviation lowers grants by $\$ 8.28$ or 11 percent. Raising state expenditures by a standard deviation raises grants by $\$ 41.24$ or 57 percent of the mean annual grant. The much larger effect 
of state expenditures on grants is due entirely to the estimated coefficients, the standard deviation of local expenditures is actually higher than state expenditures, $\$ 165$ to $\$ 133$. Variations in state expenditures are far and away the most influential determinant of federal grants.

Like the New Deal, the twentieth century experience with grants has been one where economic and political factors have an impact on the allocation of federal grants to the states. Unlike the New Deal, it is difficult to make a case that Presidential politics were more important than congressional politics, both seem to be important. Quantitatively the most important congressional variables were tenure on the House Appropriations Committee and Senate majority Leader. Tenure itself, however, is not necessarily rewarded, as shown by the negative effect of Republican tenure on the Appropriations committees. Over the long term it seems that economic and fiscal factors exerted a larger effect on the allocation of grants than political factors. The economic effects work in the right way. The single most important determinant of federal grants is state expenditures. This is consistent with the way grants actually work in the United States and a more complicated picture of the process underlying the allocation of grants.

\section{Conclusions}

This paper has three conclusions. The first is econometric. When trying to disentangle the effect of economic factors and presidential and congressional politics on the allocation of federal largess to the states, it is important to keep in mind that 1) economic and political variables may affect state as well as federal behavior so that a model with endogenous grants is called for, and 2) since we know little about the specific politics of grant allocation, we should try to control for "unobservable" state and time effects. The results presented here show how 
important it is to control for both these problems. Most of the key coefficients in the twentieth century analysis are affected by changes in specification. The effects of income and urbanization on grants appear to be perverse in a simple pooled-cross sectional regression, but inclusion of fixed effects and accounting for simultaneous grants and state and local expenditures solves the problem.

Second, states matter. The structure of government in the United States in this century has moved progressively towards interdependent federalism. In this structure state governments exert independent decision making power, and their decisions have an obvious impact on the federal government. While it is common to think of the federal government as calling the tune in its relationships with the states, the reality is far more complicated.

The third conclusion is that all of the major influences on federal allocations to the states identified in this debate appear to have some effect on national policy. During the New Deal economic factors did influence spending in the way the New Dealers suggested it should have. And the positive effect of state income on federal allocations may, someday, be resolved by better information on state and local government expenditures, as is strongly suggested by the longer panel data set. Presidential politics, as measure by Wright's variables, played an important role. Whether this was purely presidential politics or whether it was what we might call national politics, isn't clear. Democrats in the House and Senate may have had a vested interest in keeping a Democrat in the White House. Presidents may have used their discretionary powers to help strategically placed Senators and Representatives. The pattern of allocation, however, in both the New Deal and longer sample suggests that national electoral outcomes do play a role in determining grant allocations. 
Congressional factors appear to be considerably more important over the long run than they were in the New Deal. The tenure of the Democrats on the House Appropriations Committee and Senate Majority Leadership exert a significant effect on grants. It is difficult to make a case, however, that either presidential or congressional influences mattered more over the longer period.

There is, however, clear support for the argument that presidential politics mattered more during the New Deal. In the panel data set for the 1930s, Wright's political variables continue to explain a good portion of the variability in grants across states, while the congressional variables all become insignificant. This is particularly important when the peculiarities of Nevada are taken into account. The importance of presidential factors is consistent with the flexibility given to Roosevelt in the New Deal programs. That flexibility was gradually taken away from Presidents, even from Roosevelt after 1937.

That presidential, congressional, economic, and fiscal factors influenced the allocation of federal grants should come as no surprise to a student of the history of fiscal structure in the twentieth century. Indeed, it would be surprising to find that only one factor was important. Intergovernmental grants have become a major part of the fiscal structure. They exist for social and economic reasons that reflect the interests of the electorate, for public finance reasons that reflect the benefits from centralized collection of revenues and decentralized administration of expenditures, as well as political reasons. Grants represent tangible benefits that can be delivered by politicians. For all these reasons grants will continue to be used for a long time, and their determinants will reflect the complex interaction of economic, fiscal, and political forces. 


\section{ENDNOTES}

1.Figures taken from Advisory Council on Intergovernmental Relations, 1994.

2.The public finance literature is review in Oates Fiscal Federalism and Gramlich, Intergovernmental Grants. For specific studies see Mel Bungey, Philip Grossman and Peter Kenyon. "Explaining Intergovernmental Grants: Australian Evidence." Applied Economics 23 (1991): 659-68; Howard A. Chernick “An Economic Model of the Distribution of Project Grants." In Fiscal Federalism and Grants-In-Aid, ed. ??? 81-103; John Yinger and Helen F. Ladd. "The Determinants of State Assistance to Central Cities." National Tax Journal 42:4 (1990): 413-28; Steven G. Craig and Robert P. Inman. "Federal Aid and Public Education: An Empirical Look at the New Fiscal Federalism." Review of Economics and Statistics 69:4 (November 1982): 541-52; Helen F. Ladd "The State Aid Decision: Changes in State and Local Aid to Local Governments, 1982-87." National Tax Journal 44:4 (December 1991): 477-496; and Holcombe, Randall G. and Asghar Zardkoohi. "The Determinants of Federal Grants." : 39399

3.The New Deal literature includes Leonard Arrington, The New Deal in the West: A Preliminary Statistical Inquiry, 38 Pacific Historical Review, 311 (1969); Arrington, Western Agriculture and The New Deal, 49 Agricultural History, 337 (1970); Don C. Reading, New Deal Activity and the States, 1933-1939, 36 J. Econ. Hist. 792 (1973); Gavin Wright, The Political Economy of New Deal Spending: An Econometric Analysis, 56 Rev. Econ. Stat. 30 (1974);John Joseph Wallis, The Birth of the Old Federalism: Financing the New Deal, 1932-1940, 44 J. Econ. Hist. 139 (1984); Wallis, Employment, Politics, and Economic Recovery During the Great Depression, 59 Rev. Econ. Stat. 516 (1987); Gary M. Anderson and Robert D. Tollison, Congressional Influence and 
Patterns of New Deal Spending, 1933-1939, 34 J. Law and Econ. 161 (1991). The structure of grant programs is considered in John Joseph Wallis The Political Economy of New Deal Fiscal Federalism, 29 Economic Inquiry, 510.

4.See Wallis, Birth of the Old Federalism, for a closer analysis of the grant numbers and problems with using the census numbers.

5.There is a larger historical literature on grants and intergovernmental relationships during the New Deal can be found in Jane Perry Clark, The Rise of a New Federalism, 1938; V.O. Key, The Administration of Federal Grants to the States, 1937; George Benson, The New Centralization, 1941; and Henry J. Bitterman, State and Federal Grants-In-Aid, 1938.

6.Both state and local governments are important in this process. But state government's received the largest share of federal grants and, as the empirical sections will demonstrate, it is state rather than local expenditures that influence the allocation of federal grants.

7.There is little alternative for the Congress and the federal grant administrators. With the exception of general revenue sharing, grant programs are intended to increase government provision of particular services. If states are allowed to reduce their expenditures by substituting federal grants for state dollars, then grants will have a smaller effect of total expenditures than if the grant structure creates incentives for larger state expenditures. See Chernick's paper for an interesting examination of the interaction between federal and local officials.

8.Local government expenditures can be treated separately from state expenditures, as will be done in the empirical section.

9. New Deal "expenditures" are the sum of grants made to states and expenditures within states made directly by the federal government. For many New Deal programs the distinction between 
direct expenditures and grants was not a clear one. For example, under FERA, relief grants were made to the states. The states then distributed the grants to local relief agencies who distributed the funds to individuals. Under the WPA, which was FERA's primary successor in 1935, state and local WPA agencies and employees were actually federal government agencies and employees. So WPA wages were given "directly" to individuals while FERA relief benefits were granted to the states. As a result, both the terms expenditures and grants are used to describe the New Deal allocations. FERA policies are described in E.A. Williams, Federal Aid for Relief, (1939) And WPA policies are described in Donald S. Howard, The WPA and Federal Relief Policy, (1943).

10.Arrington, The New Deal in the West, and Western Agriculture and the New Deal.

11.Office of Government Reports, Statistical Section, Report No. I0, Volume II, Washington D.C. 1940.

12.Wright, Political Economy of New Deal Spending.

13. Wallis, Birth of the Old Federalism.

14.Wallis, Employment, Politics, and Economic Recovery. The employment index is presented and explained in Wallis, "Employment in the Great Depression: New Data and Hypotheses." 26 Explorations in Economic History, 45 (1989).

15.Anderson and Tollison, Congressional Influence.

16.See Wright for a complete description.

17. Although Anderson and Tollison report that both Senate and House tenures are counted in months, their table of summary statistics, Table 1, p. 170, gives the average tenure in the Senate as 187 months, while the average tenure in the House is .22 months, roughly seven days. Clearly 
there was an error in their coding. Since the House tenure variables enter into every regression, my results are different than theirs, sometimes significantly so. I have dated tenure in months from the opening day of the Congressional session beginning January 3,1937 rather than in December of 1937 to facilitate collection of the panel data for the 1930 s as well as for the twentieth century. I find average Senate tenure of 176 months (compared to 187 in Anderson and Tollison's data), average House tenure of 582 months, average Senate Appropriations Committee tenure of 42 months (compared to 55 months), and average House Appropriations Committee tenure of 59 months.

Anderson and Tollison report a mean for their Senate Leadership variable of .04, implying that Senators from two states held leadership positions between 1933 and $1939(2 / 48=.04)$. In fact, three Senators held leadership positions. The President Pro Tem of the Senate was Key Pittman of Nevada throughout the period. Joseph Robinson of Arkansas was elected Majority Leader for the 73rd, 74th and 75th Congresses, spanning the years 1933 to 1939. But Robinson died on July 14, 1937 and was replaced by Alben Barkley of Kentucky on July 22. As a result, three states are included in the Senate Leadership dummy variable: Nevada, Arkansas, and Kentucky.

18. The Nevada effect can be seen in Anderson and Tollison's original estimates. When they use electoral votes per capita, the Senate leadership variable is small and statistically insignificant. When they use the state's rank in electoral votes per capita, the Senate leadership variable is large and statistically significant.

19.The instrument for the employment index in each state and year is a composite index of state employment constructed from occupational weights from the 1930 and 1940 census, and monthly 
information on national employment by industry from the BLS and Federal Reserve Board. See Wallis, Employment, Politics and Economic Recovery, for a detailed explanation.

20.This result is in a regression including the Political Productivity variable, which is based on long term voting patterns. Several different alternative ways of including recent voting in Presidential elections were tried. Many were significant in simple panels, but using 2SLS and including fixed effects always eliminated their significance and reduced the magnitude of their coefficients substantially.

21.The demographic variables are population density, percentage white, percentage male, percentage urban, population, the growth rate of total population in the preceding decade, percent of the population that is school age, and the average size of place of resident of typical urban residents. The economic and fiscal variables are real per capita income, real per capita state debt, real per capita local debt, real per capita assessed value of property, the rank of the state in per capita income tax collections, and the number of governments per capita in the state. 
TABLE 1

VARIABLE MEANS AND STANDARD DEVIATIONS

AGGREGATE VARIABLES, 1933-1939

MEAN

STANDARD

$N=48$

DEVIATION

PER CAPITA NATIONAL SPENDING

293.44

PERCENTAGE DECLINE IN INCOME

$-28.73$

5.75

178.11

UNEMPLOYMENT 1930

UNEMPLOYMENT 1937

FARM VALUE PER CAPITA

FARM POPULATION SHARE

PERCENT FEDERAL LAND

DEMOCRATIC VOTE, 1932

PER CAPITA ELECTORAL VOTES

RANK OF ELECTORAL VOTES

4.22

0.64

0.29

13.45

64.75

0.0060

24.50

SENATE LEADERSHIP

0.063

0.083

HOUSE LEADERSHIP

175.90

SENATE TENURE

582.46

HOUSE TENURE

SENATE APPROPRIATIONS

41.79

59.15

HOUSE APPROPRIATIONS

POLITICAL PRODUCTIVITY

0.041

STANDARD DEVIATION OF VOTE

10.18

7.89

2.25

0.89

0.55

0.16

20.63

12.74

0.0045

14.00

0.24

0.28

121.97

721.74

65.75

110.87

0.036

4.33

STANDARD

ANNUAL VARIABLES, 1934 TO 1939

MEAN

DEVIATION

$$
N=288
$$

PER CAPITA NATIONAL SPENDING

43.78

27.34

PERCENTAGE DECLINE IN INCOME

$-0.29$

0.08

0.29

0.16

13.45

20.45

PERCENT FEDERAL LAND

SENATE LEADERSHIP

0.042

0.20

0.042

0.20

HOUSE LEADERSHIP

175.16

114.04

SENATE TENURE

559.60

697.96

SENATE APPROPRIATIONS

42.47

65.08

67.10

109.71

HOUSE APPROPRIATIONS

0.041

0.036

10.18

4.29

85.98

9.84

EMPLOYMENT INDEX

456.85

PER CAPITA REAL INCOME

37.77

164.99

28.36 
TABLE 2

REGRESSION ESTIMATES

(T-STAT)

A\&T WRIGHT WALLIS

REPLICATED REPLICATED REPLICATED MODEL (4)

PANEL

(4)

58.41

(2.031)

(3.48)

(2.63)

11.155626

0.929547

(3.47)

0.55

(1.897)

PANEL

WIO NEVADA

(5)

$\begin{array}{llll}(2.28) & (3.47) & (1.897)\end{array}$

SENATE LEADER

169.825763
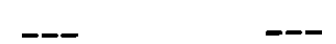

9.25

$-2.05$

(2.98)

(2.022)

$(-0.481)$

HOUSE LEADER

-29.843542
$(-0.56)$
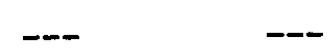

$-2.16$

$(-0.552)$

$-3.21$

$-0.207822$

$-$

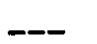

$(-1.44)$

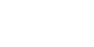

$-0.01$

$(-1.87)$

$(-1.045)$

SENATE TENURE

0.02797

(0.95)
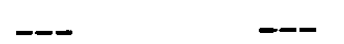

$-0.0004$

$-0.0009$

$(-0.34)$

$(-0.948)$

SENATE APPROP

0.26376

$--$

$-$

0.0100

0.0130

(1.1)

(0.767)

(1.27)

INCOME DECLINE

0.26918

(0.11)

$-0.201691$

10.806283

$(0.7)$

5.00

$-9.24$

(0.318)

$(-0.724)$

UNEMPLOYMENT

10.627561

(1.09)

$-6.056014$

$(-0.33)$

FARM VALUE

127.578423

(3.39)

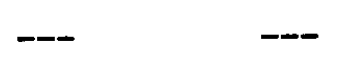

0.56

(3.111)

0.32

(2.214)

FARM POPULATION

$--\quad 118.713464$

$(0.85)$

63.180802

(3.68)

44.60

38.06

(2.611)

(2.814)

FEDERAL LAND

$$
\begin{array}{r}
4.96572 \\
(5.12)
\end{array}
$$

4.979081

0.143248

0.22

0.18

(4.87)

(1.79)

(2.767)

(2.851)

EMPLOYMENT INDE

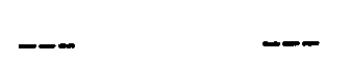

$-0.796999$

$(-3.46)$
$-0.38$

$(-2.176)$ 


\begin{tabular}{|c|c|c|c|c|c|}
\hline REAL INCOME & -- & -- & $\begin{array}{r}0.043284 \\
(3.08)\end{array}$ & $\begin{array}{r}0.018 \\
(1.316)\end{array}$ & $\begin{array}{r}0.019 \\
(1.762)\end{array}$ \\
\hline LAGGED SPENDING & -- & -- & $\begin{array}{r}0.556621 \\
(13.27)\end{array}$ & $\begin{array}{r}0.53 \\
(13.041)\end{array}$ & $\begin{array}{r}0.56 \\
(15.08)\end{array}$ \\
\hline ELECTORAL VOTES & -- & -- & -- & -- & -- \\
\hline RANK & $\begin{array}{r}3.20464 \\
(1.84)\end{array}$ & -- & -- & -- & - \\
\hline FDR VOTE & $\begin{array}{r}2.570942 \\
(1.61)\end{array}$ & -- & -- & -- & -- \\
\hline RELIEF CASES & -- & $\begin{array}{r}0.000043336 \\
(0)\end{array}$ & -- & -- & -- \\
\hline CONSTANT & $\begin{array}{r}-151.624686 \\
(-0.82)\end{array}$ & $\begin{array}{r}45.224166 \\
(0.42)\end{array}$ & $\begin{array}{r}40.986916 \\
(2.48)\end{array}$ & $\begin{array}{r}31.37 \\
(1.978)\end{array}$ & $\begin{array}{r}21.29 \\
(1.708)\end{array}$ \\
\hline OBSERVATIONS & 48 & 48 & 288 & 288 & 288 \\
\hline R-SQUARED & 0.81 & 0.73 & -- & -- & -- \\
\hline F-STAT & 14.3 & 15.9 & 129.1 & 84.6 & 77.1 \\
\hline METHOD: & OLS & OLS & 2SLS & 2SLS & 2SLS \\
\hline
\end{tabular}


TABLE 3

VARIABLE MEANS, 1932 TO 1982

MEAN

72.81

0.00012

0.12

89.95

18.42

7.21

4.13

4.05

2.11

0.02

0.02

0.02

0.02

0.43

0.50

17.45

0.56

2436.82

0.89

257.63

191.40
STANDARD

DEVIATION

64.82

0.00010

0.05

96.38

11.03

10.22

7.65

7.84

5.28

0.14

0.14

0.14

0.14

0.11

0.11

202.60

0.20

1140.93

0.11

165.54

133.05 
TABLE 4

REGRESSION RESULTS: $1932-1982$

OLS

OLS

\section{SLS \\ NO \\ FIXED \\ EFFECTS}

(1)

POLITICAL

PRODUCTIVITY

STANDARD

DEVIATION

HOUSE

TENURE

SENATE

TENURE

HOUSE DEM

APPR TENURE

HOUSE REP

APPR TENURE

SENATE DEM

APPR TENURE

SENATE REP

APPR TENURE

HOUSE

SPEAKER

HOUSE MAJORITY

LEADER

SENATE MAJORITY

LEADER

PRESIDENT

PRO TEM

PREVIOUS WINNING

PRESIDENTIAL VOTE

AVERAGE WINNING

PRESIDENTIAL VOTE
(2)

(3)
19042

(0.79)

11.89

$(0.23)$

19791

(0.82)

$-4.97$

$(-0.09)$

$-0.08$

$(-1.96)$

0.75

$(2.56)^{\star \star}$

0.72

$(2.23)^{\star *}$

$(2.75)^{\star *}$

$-0.07$

$(-0.18)$

0.28

(0.69)

$-0.04$

$(-0.08)$

11.56

(0.70)

5.12

$(0.31)$

24.45

(1.52)

$-8.43$

$(-0.48)$

---

$(-2.08)^{\star *}$

0.27

(0.88)

23.46
2SLS

WITH

FIXED

EFFECTS

(6)
(1.19)

36151

$(2.03)^{* *}$

70.64

$(2.40)^{* *}$

32.09

(0.89)

$-0.04$

$(-1.12)$

$(0.08)$

0.14

(1.37)

(0.87)

$0.47 \quad 0.50$

$(2.51)^{\star \star} \quad(2.86)^{\star *}$

$\begin{array}{rr}-0.35 & -0.44 \\ (-1.56) & (-2.09)^{\star *}\end{array}$

$\begin{array}{ll}0.13 & 0.09\end{array}$

$(0.56)$

$(0.38)$

$-0.29$

$-0.50$

$(-1.00)$

$(-1.75)^{\star}$

7.24

10.12

(0.74)

(1.03)

$2.54 \quad 2.38$

(0.26)

$(0.27)$

23.24

$(2.51)^{\star *}$

17.68

$(2.08)^{\star ~ * ~}$

6.91

(0.78)

-2.18
$(-0.21)$

$-0.33$

$-0.04$

$(-0.17)$

$(-1.94)^{*}$

0.13

0.03

$(0.73)$

$(0.17)$ 
Table 4 (continued)

$\begin{array}{ccc}\text { OLS OLS } & 2 S L S & 2 S L S \\ & \text { NO } & \text { WITH } \\ & \text { FIXED } & \text { FIXED } \\ & \text { EFFECTS } & \text { EFFECTS }\end{array}$

(1)

(2)

(3)

(6)

\begin{tabular}{|c|c|c|c|c|}
\hline $\begin{array}{l}\text { AVERAGE FARM } \\
\text { VALUE }\end{array}$ & $\begin{array}{l}0.004 \\
(0.36)\end{array}$ & $\begin{array}{l}0.004 \\
(0.34)\end{array}$ & $\begin{array}{r}-0.0123 \\
(1.82)^{*}\end{array}$ & $\begin{array}{r}-0.0002 \\
(-0.02)\end{array}$ \\
\hline $\begin{array}{l}\text { PERCENT } \\
\text { URBAN }\end{array}$ & $\begin{array}{r}-81.42 \\
(-5.00)^{\star \star}\end{array}$ & $\begin{array}{r}-86.09 \\
(-5.28)^{\star \star}\end{array}$ & $\begin{array}{r}-26.82 \\
(-2.65)^{\star \star}\end{array}$ & $\begin{array}{r}41.23 \\
(2.47)^{\star \star}\end{array}$ \\
\hline $\begin{array}{l}\text { REAL PER CAPITA } \\
\text { INCOME }\end{array}$ & $\begin{array}{r}0.053 \\
(20.71)^{\star \star}\end{array}$ & $\begin{array}{r}0.053 \\
(20.90)^{\star *}\end{array}$ & $\begin{array}{l}-0.003 \\
(-0.84)\end{array}$ & $\begin{array}{l}-0.007 \\
(-0.99)\end{array}$ \\
\hline PERCENT WHITE & $\begin{array}{r}-8.07 \\
(-0.31)\end{array}$ & $\begin{array}{r}-9.91 \\
(-0.39)\end{array}$ & $\begin{array}{r}-1.48 \\
(-0.10)\end{array}$ & $\begin{array}{l}-50.10 \\
(-1.12)\end{array}$ \\
\hline $\begin{array}{l}\text { REAL PER CAPITA } \\
\text { LOCAL EXPENDITURES }\end{array}$ & -- & -- & $\begin{array}{r}0.08 \\
(4.39)^{\star \star}\end{array}$ & $\begin{array}{r}-0.05 \\
(-1.40)\end{array}$ \\
\hline $\begin{array}{l}\text { REAL PER CAPITA } \\
\text { STATE EXPENDITURES }\end{array}$ & -- & -- & $\begin{array}{r}0.41 \\
(16.48)^{\star \star}\end{array}$ & $\begin{array}{r}0.31 \\
(5.79)^{\star \star}\end{array}$ \\
\hline CONSTANT & $\begin{array}{l}-21.57 \\
(-0.90)\end{array}$ & $\begin{array}{r}5.52 \\
(0.19)\end{array}$ & $\begin{array}{l}-8.74 \\
(-0.5)\end{array}$ & $\begin{array}{l}19.98 \\
(0.43)\end{array}$ \\
\hline R2 & 0.73 & 0.73 & -- & -- \\
\hline$F$ & 37.3 & 33.9 & 111.6 & 53.9 \\
\hline SSE & 273232 & 267026 & 89133 & 42096 \\
\hline $\begin{array}{l}\text { F-STATISTIC ON } \\
\text { FIXED EFFECTS } \\
\text { PROBABILITY }\end{array}$ & & & & 0.99 \\
\hline \multicolumn{5}{|c|}{$\begin{array}{l}\text { Note: Dependent varable in each regression is } \\
\text { real per capita grants. }\end{array}$} \\
\hline $\begin{array}{l}\text { T-statistics below each } \\
*=10 \text { PERCENT SIGNFIC } \\
* *=5 \text { PERCENT SIGNIFA }\end{array}$ & $\begin{array}{l}\text { efficient } \\
\text { NCE LEVEL } \\
\text { CE LEVEL }\end{array}$ & & & \\
\hline
\end{tabular}


TABLE 2A

REGRESSION ESTIMATES

$\begin{array}{ccc}\text { A\&T } & \text { WRIGHT } & \text { WALLIS } \\ \text { ORIGINAL } & \text { ORIGINAL } & \text { ORIGINAL } \\ \text { MODEL (4) } & & \end{array}$

(1)

(2)

(3)

\begin{tabular}{|c|c|c|c|}
\hline $\begin{array}{l}\text { POLITICAL } \\
\text { PRODUCTIVITY }\end{array}$ & -- & $\begin{array}{r}1.36 \\
(2.74)\end{array}$ & $\begin{array}{l}0.09 \\
(3.5)\end{array}$ \\
\hline $\begin{array}{l}\text { STANDARD DEV } \\
\text { OF VOTE }\end{array}$ & -- & $\begin{array}{r}0.0109 \\
(2.06)\end{array}$ & $\begin{array}{r}0.0009 \\
(3.4)\end{array}$ \\
\hline SENATE LEADER & $\begin{array}{r}321.01 \\
(3.9)\end{array}$ & -- & --- \\
\hline HOUSE LEADER & $\begin{array}{l}22.07 \\
(0.38)\end{array}$ & -- & --- \\
\hline SENATE TENURE & $\begin{array}{r}-0.06 \\
(-0.41)\end{array}$ & -- & -- \\
\hline HOUSE TENURE & $\begin{array}{r}127.16 \\
(0.91)\end{array}$ & --- & -- \\
\hline SENATE APPROP & $\begin{array}{r}0.45 \\
(2.27)\end{array}$ & -- & --- \\
\hline INCOME DECLINE & $\begin{array}{r}1.49 \\
(0.39)\end{array}$ & $\begin{array}{r}0.54 \\
(1.36)\end{array}$ & $\begin{array}{r}-0.000009 \\
(-0.4)\end{array}$ \\
\hline UNEMPLOYMENT & $\begin{array}{l}20.42 \\
(1.97)\end{array}$ & $\begin{array}{r}-0.0043 \\
(-0.23)\end{array}$ & -- \\
\hline FARM VALUE & $\begin{array}{r}233.06 \\
(5.07)\end{array}$ & -- & -- \\
\hline FARM POPULATION & --- & $\begin{array}{l}0.238 \\
(1.95)\end{array}$ & $\begin{array}{r}0.045 \\
(3.8)\end{array}$ \\
\hline FEDERAL LAND & $\begin{array}{r}4.84 \\
(5.11)\end{array}$ & $\begin{array}{r}0.0048 \\
(4.79)\end{array}$ & $\begin{array}{r}0.00019 \\
(3.1)\end{array}$ \\
\hline EMPLOYMENT INDEX & $-\cdots$ & -- & $\begin{array}{r}-0.00056 \\
(-4.6)\end{array}$ \\
\hline
\end{tabular}


REAL INCOME

LAGGED SPENDING

ELECTORAL VOTES

RANK

FDR VOTE

RELIEF CASES

CONSTANT

OBSERVATIONS

R-SQUARED

F

METHOD:
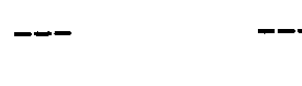

$-$

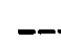

3.33

(2.23)

$$
1.49
$$

(0.96)

$$
\begin{array}{r}
-- \\
-162.03 \\
(-0.72)
\end{array}
$$

48

0.87

31.28

OLS
48

288

0.000028

(2.3)

0.56

(14)
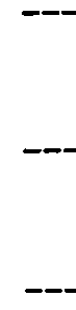

0.093

(0.34)

0.058

0.028

(2.6)

. 30.1

OLS 2SLS 


\section{BiBLIOGRAPHY}

Advisory Council of Intergovernmental Relations, Significant Features of Fiscal Federalism 1994. Washington, 1994.

Alston, Lee J. and Joseph P. Ferrie. "Patrenalism in Agricultural Labor Contracts in the U.S. South: Implications for the Growth of the Welfare State." American Economic Review 83:4 (September 1993): 852-76.

Anderson, Gary M. and Robert D. Tollison. "Congressional Influence and Patterns of New Deal Spending, 1933-1939." Journal of Law and Economics 34 (April 1991): 161-75.

Arrington, Leonard. "The New Deal in the West: A Preliminary Statistical Inquiry." Pacific Historical Review 38 (August 1969): 311-16.

Arrington, Leonard. "Western Agriculture and The New Deal." Agricultural History 49 (October 1970): 337-51.

Benson, George. The New Centralization, New York: 1941.

Bitterman, Henry J. State and Federal Grants-In-Aid, Chicago, 1938.

Bungey, Mel, Philip Grossman and Peter Kenyon. "Explaining Intergovernmnetal Grants: Australian Evidence." Applied Economics 23 (1991): 659-68.

Chernick, Howard A. "An Economic Model of the Distribution of Project Grants." In Fiscal Federalism and Grants-In-Aid, ed. ??? 81-103.

Clark, Jane Perry. The Rise of a New Federalism. Columbia, 1938.

Craig, Steven G. and Robert P. Inman. "Federal Aid and Public Education: An Empirical Look at the New Fiscal Federalism." Review of Economics and Statistics 69:4 (November 1982): 541-52.

Holcombe, Randall G. and Asghar Zardkoohi. "The Determinants of Federal Grants." : 393-99.

Howard, Donald S. The WPA and Federal Relief Policy, 1943.

Inman, Robert P. "Federal Assistance and Local Services in the United States: The Evolution of a New Federalist Fiscal Order." In Fiscal Federalism: Quantitative Studies, ed Harvery Rosen. Chicago: 1988 33-77.

Gramlich, E. M. "Intergovernmental Grants: A Review of the Empirical Literature." In The Political Economy of Fiscal Federalism. Wallace E. Oates, ed. Lexington, 1977. 
Key, V. O. The Administration of Federal Grants to the States. Chicago: 1937.

Ladd, Helen F. "The State Aid Decision: Changes in State and Local Aid to Local Governments, 1982-87." National Tax Journal 44:4 (December 1991): 477-496.

Oates, Wallace E. Fiscal Federalism. New York: 1972.

Office of Government Reports, Statistical Section, Report No. 10, Volume II. Washington, D.C. 1940.

Patterson, James T. Congressional Conservatism and the New Deal. Lexington, Kentucky: 1967.

Reading, Don. "New Deal Activity and the States." Journal of Economic History 36 (December 1973): 792-810.

Wallis, John Joseph. "The Birth of the Old Federalism: Financing the New Deal." Journal of Economic History 44 (June 1984): 139-59.

Wallis, John Joseph. "The Political Economy of New Deal Fiscal Federalism." Economic Inquiry 29 (July 1991): 510-24.

Wallis, John Joseph. "Employment in the Great Depression: New Data and Hypotheses. Explorations in Economic History 26, (1989): 45-72.

Wallis, John Joseph. "Employment, Politics, and Economic Recovery During the Great Depression." The Review of Economics and Statistics 59 (August 1987): 516-520.

Williams, E. A. Federal Aid for Relief. 1939.

Wright, Gavin. "The Political Economy of New Deal Spending." The Review of Economics and Statistics 59 (February 1974): 30-38.

Yinger, John and Helen F. Ladd. "The Determinants of State Assistance to Central Cities." National Tax Journal 42:4 (1990): 413-28. 